\title{
Depression among Nurses in Pabna Mental Hospital, Pabna
}

\author{
Md. Fajlul Kabir Bhuiyan *1, Md. Masud Rana Sarker ${ }^{2}$, \\ Chowdhury Rakibuzzaman ${ }^{3}$, Nahreen Rahman ${ }^{4}$
}

\section{Abstract}

Introduction: Every day, nurses experience a great deal of stress. They face problems at work, people relying on them for their care, and also tons of responsibilities piling up at home. Psychological stress is common in hospital ward and associated with depression. Only few studies are done concerning mental health of Nurses in Bangladesh. The study was carried out with a view to find out the prevalence of depression among nurses at Mental Hospital, Pabna, Bangladesh. Materials \& Methods: A cross sectional, questionnaire-based survey was carried out among the 125 nurses of Mental Hospital, Pabna. The studywas conducted between January to February 2019. The depression levels were assessed using Zung depression scale. Nurses were asked to complete the questionnaire and then the depression levels calculated. Result: The overall prevalence of depression among the nurses was 4.13 percent. The prevalence of depression was 4.5 percent among female nurses versus 2.94 percent in male nurses. Conclusion: The prevalence of depression is seen especially innurses. So, attempts should be made to alleviate the stressors.

Keywords: Depression, Nurse, Zung depression scale.

Number of Tables: 02; Number of References: 23; Number of Correspondences: 04

*1. Corresponding Author:

Dr. Md. Fajlul Kabir Bhuiyan

MBBS, Medical Officer

Mental Hospital, Pabna, Bangladesh.

Email: fajlulkabir81@yahoo.com

Mobile: 00-88-01712-836989

2. Dr. Md. Masud Rana Sarker

FCPS, Medical Officer

Mental Hospital, Pabna, Bangladesh.

3. Dr. Chowdhury Rakibuzzaman

MCPS, Medical Officer

Mental Hospital, Pabna, Bangladesh.

4. Dr. Nahreen Rahman

M Phil, Lecturer

Department of Microbiology

Rajshahi Medical College, Rajshahi, Bangladesh.

\section{Introduction}

Depression is one of the most commonly diagnosed mental disorders. According to the World Health Organization (WHO), about 300 million people suffer from depression worldwide, which represents one of the leading causes of disability and global burden of diseases ${ }^{1}$. Nurses are known to be the victims of tremendous mental stress. The personal and social sacrifice they have to make in order to maintain a good patient care result in a highly stressful environment puts them under a lot of stress. Depression imposes a considerable economic burden on the society; therefore, prevention plays an important role in saving resources and improving quality of life ${ }^{2}$. By 2030, depression is expected to become the second cause of disability and co-morbidities in developing countries $^{3}$, profoundly impacting people's performance and quality of life. Furthermore, an anticipation of age-of-onset is expected ${ }^{4}$. From an etiopathogenetic standpoint, hereditary genetic and biochemical causes can cause depression, disturbing communication between nerve cells ${ }^{5}$. Social and family problems and employment conditions can be among the causes of depression ${ }^{6}$. This disease severely impairs familiar and social sphere, as well as professional working, leading, in some cases, to suicide ${ }^{7}$. Doctors, nurses, and other hospital service providers are among a group at high risk for developing depression. Doctors, nurses, and other hospital service providers are among a group at high risk for developing depression ${ }^{8}$. It is estimated that depression has a greater impact on job performance than chronic diseases, such as arthritis, blood pressure, backache, and diabetes ${ }^{9}$. Nursing is among occupational groups at high risk for depression due to harsh working conditions ${ }^{10}$. Several studies have examined the prevalence of depression among nurses. In 2 studies conducted in the USA, the prevalence of depression was reported to range from $18 \%$ to $41 \%^{11,12}$. However, only few studies are done in nurses of Bangladesh. Thus, we carried out a 20 questionnaire based cross sectional study to find out the prevalence of depression in nurses.

\section{Materials and Methods}

The Study was a descriptive cross sectional study conducted at Mental Hospital, Pabna, Bangladesh during the period of January 2019 to February 2019. 125 nurses were included in the study after randomized sampling. The recruited nurses were informed about the purpose of study and explained about the general instructions.Informed consent was taken prior to the study. The nurses were allowed to respond in their own time and privacy. The participation was entirely voluntary. The study was approved by the Research Ethical Committee. Then they were 
given the questionnaires which comprised of personal data, Zung Depression Inventory \& stress inducing factors.

- Personal Data: This included age, sex, religion and home district.

- Zung Depression Scale: It is a 20 itemed self rated questionnaire which assess the level of depression symptoms ${ }^{13}$. It has already been used in primary care and community settings and as a screen for depression ${ }^{14}$. It contains 10 positive questions for e.g. "I eat as much as I used to" and 10 negative questions for e.g. "I notice that I am losing weight". Answers thus obtained are scored between one to four for each question with a total score ranging from 20 to 80 . A score less than 50 were considered to represent a case with no depression while a score $\geq 50$ was considered to represent a case with depression.

- Stress inducing factors: After in-depth literature review and peer consultation, five most important stress inducing factors were selected. The nurses were asked to strike the factors they thought to be important from the following.

a) Hospital stress

b) Relationships problem

c) Hectic lifestyle

d) Future concerns

e) Familial problem

Data were analyzed by using SPSS software (Version: 16) and then the results were interpreted.

\section{Results}

Out of the 125 questionnaires distributed to nurses 121 were returned completed, giving a response rate of $96.8 \%$. Out of the 121 respondents, 87 were females and 34 males. The mean age of study subjects was 35.67 years and a range of 26 to 55 years. Overall prevalence of depression in nurses was found to be $4.13 \%$. The incidence of depression was found to be more among female nurses versus male nurses which is shown in table.

Table - I: Distribution of the respondents by sex of the nurses.

\begin{tabular}{lcc}
\hline \multicolumn{1}{c}{ N=121 } & Total & $\begin{array}{c}\text { Percentage } \\
\text { (\%) }\end{array}$ \\
\hline No. of depressed Male & 1 & 2.94 \\
No. of depressed Female & 4 & 4.5 \\
\hline
\end{tabular}

Table -II: Distribution of the respondents by stress inducing factors.

\begin{tabular}{lcc}
\hline \multicolumn{1}{c}{ Factor } & Total & $\begin{array}{c}\text { Percentage } \\
\text { (\%) }\end{array}$ \\
\hline Hospital stress & 5 & 4.13 \\
Relationships problem & 4 & 3.3 \\
Hectic lifestyle & 4 & 3.3 \\
Future concerns & 5 & 4.13 \\
Familial problem & 3 & 2.4 \\
\hline
\end{tabular}

\section{Discussion}

The response rate of $96.8 \%$ renders an adequate sample of population studied to fulfill the objectives of the study. The findings show the prevalence of depression (4.13\%) in Mental Hospital, Pabna (Table-I). In another study conducted in China, the prevalence of depression among nurses was $38 \%{ }^{15}$. Also in two studies conducted in Taiwan, the prevalence was $52.5 \%$ and $27.7 \%$, respectively ${ }^{16,17}$. Canada, France, and the USA reported a prevalence rate of $10 \%$ to $40 \%{ }^{18,19,20,21}$.Various factors, such as differences in personality, cultural, social, and working conditions may explain differences in the prevalence of depression among nurses in different countries around the world. Moreover, different methodological designs and different tools used for assessing depression could play a role in explaining these discrepancies.In our study,the prevalence of depression was found to be less in the nurses.This finding could be due to less hospital,familial and relationship stress (Table-II). In Bangladesha rural community-based study showed an overall prevalence of psychiatric disorders as $16.5 \%$; notably, half of the sufferers had depressive disorders $(8 \%)$ and a third had anxiety disorders $(5 \%)^{22}$. On the other hand, another study on females in a rural setting reported $16.4 \%$ had mental disorders with depression being the single most common disorder $(8.9 \%)^{23}$. In table no: I, we found that a gender difference regarding the association with depression was noted where female nurses reported a higher. This gender variation in depressive status in nurses could be the reflection of usual trend of high prevalence of depression in females as in the general population. However, the study has been able to throwsome light about the mental health of nurses. There were several limitations to the study. Our study only included 125 respondents due to unavailability. Other stressors were not assessed.

\section{Conclusion}

The results revealed a picture of the prevalence of depression in nurses in a mental hospital in Bangladesh. They should be supported by counseling. By identifying the symptoms of depression and the stress inducing factors at an early stage hopefully the psychological morbidity among nurses can be prevented and the ones in morbid state can be helped to seek the professional.

\section{Conflict of Interests: None.}

\section{Acknowledgement}

The authors would like to thank nurses of Mental hospital, Pabnafor their participation in the study. Also special thanks to Dr. Masud Rana Sarker, Psychiatrist and Professor Dr.Tanmoy Prokash Biswas, Director for his valuable analysis and advice on statistics and verifying the whole manuscript.

\section{References}

1. World health organization. Depression 2017; Available from: http://www. who.int/mediacentre/factsheets/fs369/en/. Accessed on 6 March, 2019. 
2. Luppa M, Heinrich S, Angermeyer MC, König HH, Riedel-Heller SG. Cost-of-illness studies of depression: a systematic review. J Affect Disord. 2007; 98: 29-43.

https://doi.org/10.1016/j.jad.2006.07.017

PMid:16952399

3. Mathers CD, Loncar D. Projections of global mortality and burden of disease from 2002 to 2030. PLoS Med. 2006; 3: e442.

https://doi.org/10.1371/journal.pmed.0030442

PMid:17132052 PMCid:PMC1664601

4. Ustün TB, Ayuso-Mateos JL, Chatterji S, Mathers C, Murray CJ. Global burden of depressive disorders in the year 2000. Br J Psychiatry. 2004; 184: 386-92.

https://doi.org/10.1192/bjp.184.5.386

PMid:15123501

5. Goodwin GM. Depression and associated physical diseases and symptoms. Dialogues ClinNeurosci. 2006; 8: 259-65.

6. Kessler RC, Greenberg PE, Mickelson KD, Meneades LM, Wang PS. The effects of chronic medical conditions on work loss and work cutback. J Occup Environ Med. 2001; 43: $218-25$.

https://doi.org/10.1097/00043764-200103000-00009

PMid:11285869

7. Mata DA, Ramos MA, Bansal N, Khan R, Guille C, Di Angelantonio E., et al. Prevalence of Depression and Depressive Symptoms Among Resident Physicians: A Systematic Review and Meta-analysis. JAMA. 2015; 314: 2373-83.

https://doi.org/10.1001/jama.2015.15845

PMid:26647259 PMCid:PMC4866499

8. Callaghan P, Tak-Ying SA, Wyatt PA. Factors related to stress and coping among Chinese nurses in Hong Kong. J AdvNurs. 2000; 31: 1518-27.

https://doi.org/10.1046/j.1365-2648.2000.01434.x PMid:10849166

9. Kessler RC, EJ B. The epidemiology of depression across cultures. Annu Rev Public Health. 2013; 34: 119-38. https://doi.org/10.1146/annurev-publhealth-031912-114409 PMid:23514317 PMCid:PMC4100461

10. Oates J, Drey N, Jones J. Associations between Age, Years in Post, Years in the Profession and Personal Experience of Mental Health Problems in UK Mental Health Nurses. Issues Ment Health Nurs. 2017:1-9.

https://doi.org/10.1080/01612840.2017.1324927

PMid:28574781

11. Letvak S, Ruhm CJ, McCoy T. Depression in hospitalemployed nurses. Clin Nurse Spec. 2012; 26: 177-82.

https://doi.org/10.1097/NUR.0b013e3182503ef0

PMid:22504476

12. Ruggiero JS. Health, work variables, and job satisfaction among nurses. J Nurs Adm. 2005; 35: 254-63. https://doi.org/10.1097/00005110-200505000-00009

PMid:15891489

13. Zung WWK. A self-rating depression scale. Arch Gen Psy. 1965; 12: 63- 70.

https://doi.org/10.1001/archpsyc.1965.01720310065008

14. Meakin C. Screening for depression in the medically ill. Br J Psy. 1992; 160: 212-6.

https://doi.org/10.1192/bjp.160.2.212

15. Gong Y, Han T, Yin X, Yang G, Zhuang R, Chen Y., et al. Prevalence of depressive symptoms and work-related risk factors among nurses in public hospitals in southern China: A cross-sectional study. Sci Rep. 2014; 4: 7109.

https://doi.org/10.1038/srep07109

PMid:25427988 PMCid:PMC5384112

16. Chang Y, Wang PC, Li HH, Liu YC. Relations among depression, self-efficacy and optimism in a sample of nurses in Taiwan. J NursManag. 2011; 19: 769-76.

https://doi.org/10.1111/j.1365-2834.2010.01180.x

PMid:21899630

17. Lin HS, Probst JC, Hsu YC. Depression among female psychiatric nurses in southern Taiwan: main and moderating effects of job stress, coping behaviour and social support. J ClinNurs. 2010; 19: 2342-54.

https://doi.org/10.1111/j.1365-2702.2010.03216.x

PMid:20659207

18. Letvak S, Ruhm CJ, McCoy T. Depression in hospital-employed nurses. Clin Nurse Spec. 2012; 26: 177-82.

https://doi.org/10.1097/NUR.0b013e3182503ef0

PMid:22504476

19. Ruggiero JS. Health, work variables, and job satisfaction among nurses. J Nurs Adm. 2005; 35: 254-63.

https://doi.org/10.1097/00005110-200505000-00009

PMid:15891489

20. Nourry N, Luc A, Lefebvre F, Sultan-Taïeb H, Béjean S. Psychosocial and organizational work environment of nurse managers and self-reported depressive symptoms: cross-sectional analysis from a cohort of nurse managers. Int J Occup Med Environ Health. 2014; 27: 252-69.

https://doi.org/10.2478/s13382-014-0264-X

PMid:24729300

21. Ohler MC, Kerr MS, Forbes DA. Depression in nurses. Can J Nurs Res. 2010; 42: 66-82.

22. MonawarHosain GM, Chatterjee N, Ara N, Islam T. Prevalence, pattern and determinants of mental disorders in rural Bangladesh. Public Health. 2007; 121(1): 18-24.

https://doi.org/10.1016/j.puhe.2006.06.018

PMid: 17055545

23. Ara N, Hossain GMM, Islam MT. Women mental health in rural part of Bangladesh. Bang J Psychiatry. 2001; 15(2): 5-10. 